CALIFORNIA

INSECTS 


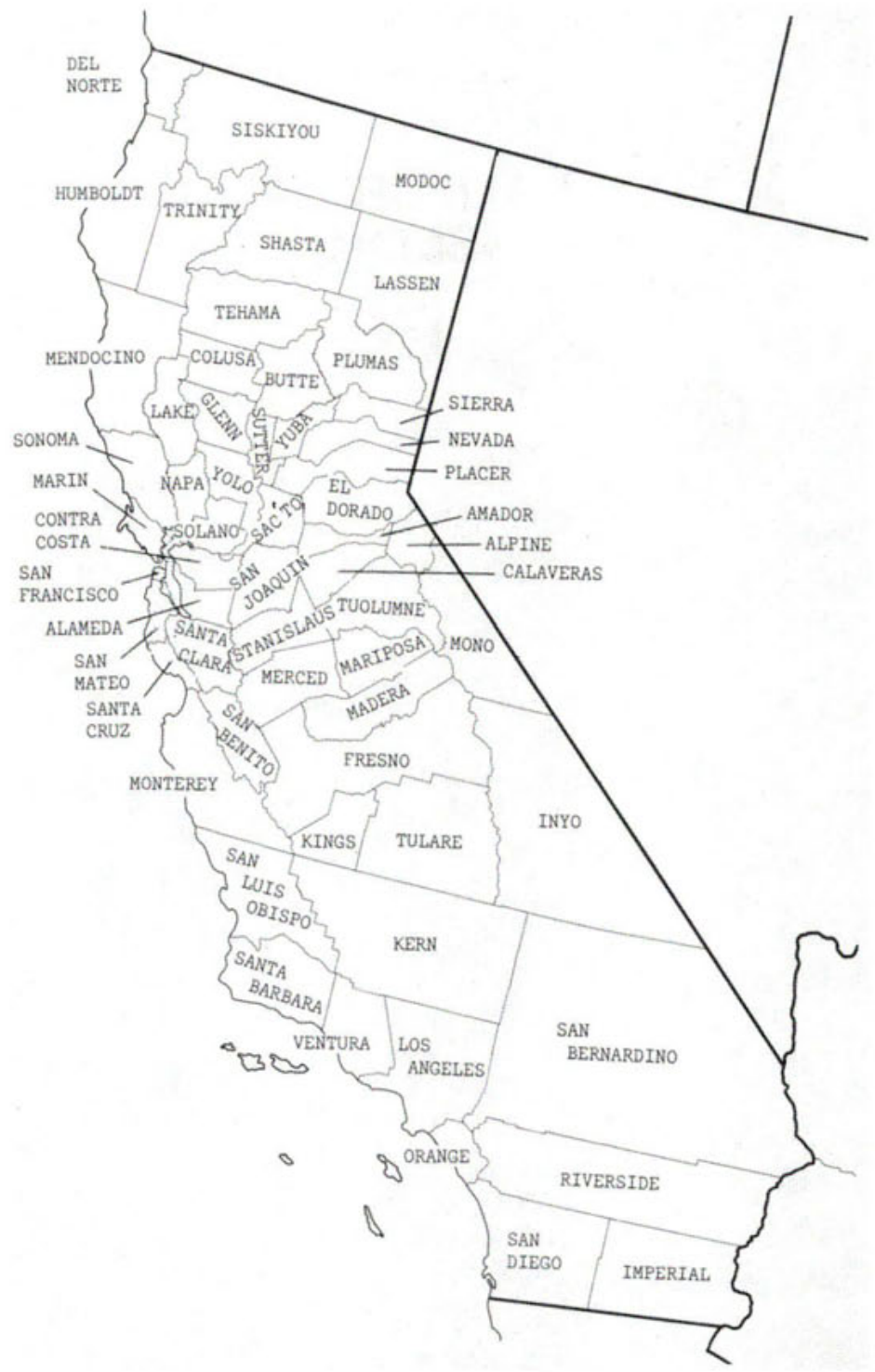

Map 1 Outline map of California, showing counties. 
California Natural History Guides: 44

\title{
CALIFORNIA INSECTS
}

\author{
BY \\ JERRY A. POWELL \\ AND \\ CHARLES L. HOGUE
}

DRAWINGS BY

CHARLES L. HOGUE 


\title{
CALIFORNIA NATURAL HISTORY GUIDES \\ Arthur C. Smith, General Editor
}

\author{
Advisory Editorial Committee \\ Raymond F. Dasmann \\ Mary Lee Jefferds \\ A. Starker Leopold \\ Robert Ornduff \\ Robert C. Stebbins
}

COVER IlluSTRATIONS: Upper left: Common Hover Fly, Eupeodes volucris (p. 160). Upper right: Yellow-Spotted Tiger Moth, Lophocampa maculata (larva) (p. 224). Lower left: Anise Swallowtail, Papilio zelicaon (p. 257). Lower right: Convergent Ladybird Beetle, Hippodamia convergens (p. 298).

\author{
University of Califomia Press \\ Berkeley and Los Ángeles, California \\ University of California Press, Ltd. \\ London, England
}

Copyright (C) 1979 by The Regents of the University of California

ISBN: 0-520-03782-0 (alk. paper)

Library of Congress Catalog Card Number: 78-62876

Printed in the United States of America

$$
\begin{array}{llllllll}
3 & 4 & 5 & 6 & 7 & 8 & 9 & 10
\end{array}
$$

The paper used in this publication is both acid-free and totally chlorine-free (TCF). It meets the minimum requirements of American Standard for Information Sciences-Permanence of Paper for Printed 